\title{
Trends of vasopressor using in medical intensive care unit: a 7-year cohort study
}

\author{
N Srivali, , C Thongprayoon, W Cheungpasitporn, K Kashani \\ From ESICM LIVES 2015 \\ Berlin, Germany. 3-7 October 2015
}

\section{Introduction}

The use of vasopressor was common in medical intensive care unit (MICU). Due to the lack of conclusive evidence in superiority in efficacy among various types of vasopressors, the choice of vasopressor use mainly depends on the physician preference.

\section{Objectives}

This study aims to describe the prevalence of vasopressor use and the trend in the use of each vasopressor medication in MICU over the past 7 years.

\section{Methods}

This is a descriptive study conducted at a tertiary referral hospital. All MICU admissions at our institution between January 2007 and December 2013 were included in this study. The use of vasopressor within given ICU day (12.00 am - $11.59 \mathrm{pm})$ during ICU stay was reviewed. Vasopressors were defined as the continuous intravenous administration of norepinephrine, epinephrine, dopamine, phenylephrine, or vasopressin regardless of duration and dosage. The use of each vasopressor was reported as the vasopressor utilization index (VUI), using the following formula Vasopressor utilization index $(\mathrm{VUI})=$ The total number of ICU days on a given vasopressor/The total number of ICU days on any vasopressor.

\section{Results}

A total of 16,863 unique patients had 17,164 MICU admissions in the course of study, (55,391patient"ICU day).Out of 7,739 ICU days with vasopressor use, norepinephrine was used for 6,414 (83\%), vasopressin for $1,960(25 \%)$, phenylephrine for $772(10 \%)$, dopamine for $623(8 \%)$, and epinephrine for 323 (4\%). From 2007 through 2013, there was an increasing trend in the use of norepinephrine

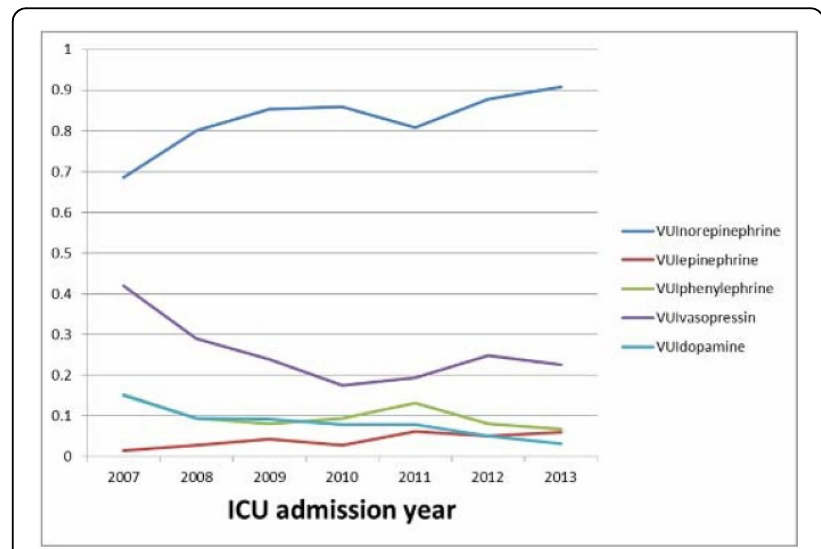

Figure 1 Trend of vasopresser using.

(VUI ${ }_{\text {norepinephrine }}$ was 0.69 in 2007 and 0.91 in 2013) and an slight increasing trend in the use of epinephrine (VUI epinephrine was 0.01 in 2007 and 0.06 in 2013). There was a decreasing trend in the use of dopamine (VUI $\mathrm{V}_{\text {dopamine }}$ was 0.15 in 2007 and 0.03 in 2013), vasopres$\sin \left(\mathrm{VUI}_{\text {vasopressin }}\right.$ was 0.42 in 2007 and 0.22 in 2013), and a slight downward trend in the use of phenylephrine.

\section{Conclusions}

Norepinephrine is the most commonly used vasopressor in MICU. The use of norepinephrine and epinephrine are in upward trajectory.

Published: 1 October 2015

\section{References}

1. De Backer D, Biston P, Devriendt J, Madl C, Chochrad D, Aldecoa C, Brasseur A, Defrance $P$, Gottignies $P$, Vincent $J$ : Comparison of dopamine and norepinephrine in the treatment of shock. N Engl J Med 2010, 362(9):779-789. 
2. Russell JA, Walley KR, Singer J, Gordon AC, Hebert PC, Cooper DJ,

Holmes CL, Mehta S, Granton JT, Storms MM, et al: Vasopressin versus norepinephrine infusion in patients with septic shock. N Engl J Med 2008, 358(9):877-887.

doi:10.1186/2197-425X-3-S1-A960

Cite this article as: Srivali et al:: Trends of vasopressor using in medical intensive care unit: a 7-year cohort study. Intensive Care Medicine Experimental 2015 3(Suppl 1):A960.

\section{Submit your manuscript to a SpringerOpen ${ }^{\circ}$ journal and benefit from:}

- Convenient online submission

- Rigorous peer review

- Immediate publication on acceptance

- Open access: articles freely available online

- High visibility within the field

- Retaining the copyright to your article

Submit your next manuscript at $\gg$ springeropen.com 